June 1995

\title{
A Mesmerizing Book
}

Daniel A. Monti, MD

Thomas Jefferson University Hospital

Follow this and additional works at: https://jdc.jefferson.edu/jeffjpsychiatry

Part of the Psychiatry Commons

Let us know how access to this document benefits you

\section{Recommended Citation}

Monti, MD, Daniel A. (1995) "A Mesmerizing Book," Jefferson Journal of Psychiatry. Vol. 12 : Iss. 2 , Article 11.

DOI: https://doi.org/10.29046/JJP.012.2.008

Available at: https://jdc.jefferson.edu/jeffjpsychiatry/vol12/iss2/11

This Article is brought to you for free and open access by the Jefferson Digital Commons. The Jefferson Digital Commons is a service of Thomas Jefferson University's Center for Teaching and Learning (CTL). The Commons is a showcase for Jefferson books and journals, peer-reviewed scholarly publications, unique historical collections from the University archives, and teaching tools. The Jefferson Digital Commons allows researchers and interested readers anywhere in the world to learn about and keep up to date with Jefferson scholarship. This article has been accepted for inclusion in Jefferson Journal of Psychiatry by an authorized administrator of the Jefferson Digital Commons. For more information, please contact: JeffersonDigitalCommons@jefferson.edu. 


\title{
Book Reviews
}

\section{"A Mesmerizing Book"}

\author{
HYPNOSIS IN THE RELIEF OF PAIN \\ Ernest R. Hilgard and Josephine R. Hilgard \\ Brunner/Mazel, Inc., New York \\ 1994, paperback, $\$ 28.95,294$ pgs.
}

\section{Daniel A. Monti, M.D.}

Fascination with the effects of words and ideas upon our physical well-being dates back to ancient times. As early as 1,500 B.C., there are records that describe the practice of magical incantation and ritual that evidently evoked healing by facilitating the experience of altered states, belief, and expectancy. Such practices were continued through the middle ages, when the "healing touch" was used to evoke cure. Even the early "physicians," such as Albert Magnus, Paracelsus, and Robert Fludd, used incantations, faith, and magical belief systems to facilitate healing. About two centuries ago, there was a resurgence of the public's captivation with hypnotic-like behaviour when an Austrian physician, Franz Anton Mesmer (17341815), introduced a form of hypnosis called animal magnetism. Mesmer made such an impact that his technique came to be known as mesmerism, a word which is still sometimes used as a synonym for hypnosis. The cultivation of hypnosis since that time is a story of miraculous anecdotes, political upheavals, and various attempts at scientific inquiry. Hypnosis remains ever present in clinical practice. While there is considerable debate over which disorders are appropriately treated with hypnosis, most clinicians agree that at least some people benefit from its use in pain management.

In Hypnosis In The Relief of Pain, Ernest and Josephine Hilgard attempt to examine hypnosis objectively and to specifically address its use in conditions of pain. The book was originally published in 1975, and then again in 1983 with the addition of a new foreward and a final chapter on recent developments. The current edition is a reprint of the 1983 version, with the mere addition of a new foreward.

The book begins with a brief historical overview. There is then a discussion of hypnotic responsiveness, and the Stanford Hypnotic Susceptibility scale is introduced. This tool was developed by the authors to evaluate certain concepts scientifi-

Daniel A. Monti, M.D. is a third year psychiatry resident at Thomas Jefferson University Hospital in Philadelphia and is also serving as the APA Burroughs Welcome Fellow. 
cally. For example, it has been shown that hypnotic responsiveness can to some degree be trained, although improvement is proportional to baseline responsiveness. Hence, those who are highly responsive to begin with will benefit most from further training. Baseline susceptibity does not seem to be correlated with a particular personality type. Rather, there is a relationship between hypnotic susceptibility and right brain hemispheric preference; as well as greater proportion of EEG-alpha time spent in the resting waking state.

The concept of pain itself is discussed, as well as distinguishing pain from suffering and mental anguish. There is also a brief overview of the gate control theory of pain. Unfortunately, this entire section is somewhat disappointing, as it has not been updated since the original publication two decades ago. This is unfortunate given the wealth of literature and theoretical constructs since developed. This shortcoming is forgivable, as the remainder of the book is dedicated to the use of hypnosis in pain management, and contains information that continues to be highly pertinent.

A good predictor of hypnotic analgesia is initial susceptibility. High responders are able to achieve a state of analgesia, even though physiological indicators of pain, such as heart rate and blood pressure, remain unaffected. Also, the analgesia is not due to relaxation, but rather to specific suggestions for pain reduction. Anxiety reduction can occur with hypnosis, but that more affects pain tolerance, much like a sedative does.

Hypnotic pain reduction procedures are applicable to many types of situations: when the pain is short and episodic, as in most dental procedures; when it is longer but with known termination, as in the labor of childbirth and surgery; or even when it is protracted over days or weeks, as in cancer or burns. For example, the method of glove anesthesia, with the transfer of the insensitivity to another area, can be used in all of these cases. Similarly, displacement of pain from one area to another and conversion to a more acceptable symptom are widely used practices, as is removal from the scene through fantasy.

This work by the Hilgards is a classic in the hypnosis literature. Its shortcomings in dated material are redeemed by the intriguing concepts which it introduces, such as the "hidden observer," a profound phenomenom whose explanation remains elusive today. The Hilgards' Stanford Hypnosis Laboratory laid a distinct foundation for understanding human consciousness, uniting scrupulous scientific investigation with clinical techniques. The book is clearly written and well organized, and is certainly a must read for those interested in hypnosis or pain management, subjects which often receive too little attention from residency training programs. Keep in mind, however, that this is not a "how to" book, rather it provides a theoretical framework to a subject that is often seen as vague and mysterious. 